\title{
SOCIALINĖS APLINKOS VEIKSNIAI, TURINTYS İTAKOS JAUNŲJŲ LENGVAATLEČIŲ SPORTO PRATYBOMS IR VARŽYBOMS
}

Nelẻ Žilinskienè

Vilniaus pedagoginis universitetas, Vilnius, Lietuva

\begin{abstract}
Nelẻ Žilinskienė. Socialinių mokslų daktarè. Vilniaus pedagoginio universiteto Sporto metodikos katedros lektorẻ. Mokslinių tyrimų kryp-
\end{abstract} tis - sportininku rengimas.

\section{SANTRAUKA}

Šiuolaikinè socialine sporto problema yra mažéjantis mokiniu, norinčiu kultivuoti lengvaja atletika, skaičius. Šiai situacijai ̌takos gali turèti individualūs gebejimai, saviraiškos galimybès, amžius, socialinè ugdomoji aplinka, tèvu pritarimas ir skatinimas, sporto materialine baze ir kiti veiksniai. Tikètina, kad socialinè aplinka — teigiamas tèvu požiūris i sportinę veikla, materialinè bazé, sportavimo ir mokymosi suderinimas — skatina jaunuosius lengvaatlečius treniruotis, tobulinti sportinius gebejjimus.

Tyrimo tikslas — nustatyti ir palyginti jaunučiu ir jauniu socialinès aplinkos veiksnius, turinčius itakos Lietuvos lengvaatlečiu sporto pratyboms ir varžyboms.

Anketine apklausa buvo atliekama po pratybu ir varžybu, iš anksto susitarus su treneriais, dalyvaujant tyrèjui. Tiriamaja imti sudare 367 13-17 metu lengvaatlečiai - 179 merginos ir 188 vaikinai, parinkti serijiniu büdu.

Nustatytas teigiamas tèvu požiūris i lengvosios atletikos pratybas: $71 \%$ tèvu tiki, kad ju vaikai gali pasiekti geru sportiniu rezultatu, 67\% tèvu džiangiasi, nes ju vaikai turiningai leidžia laisvalaiki, 54\% nori, kad vaiku sportiniai rezultatai bütu geresni.

Tik 32\% apklaustu lengvaatlečiu tenkina Lietuvos sporto baziu būklè ir kokybè, 53\% tenkina iš dalies. Jaunučius statistiškai patikimai $(p<0,001)$ dangiau tenkina sporto baziu bükle ir kokybè, lyginant su jauniais.

Lietuvos jaunučiu ir jauniu sportinis stažas dažniausiai svyruoja nuo vieneriu iki ketveriu metu (13-24\% tiriamuju). Tai rodo, kad dauguma ju pradeda sportuoti büdami dešimties metu amžiaus. Désninga, kad vieneriu ir treju metu sportini stažq turi jaunučiai, o ketveriu ir daugiau - jauniai $(p<0,001)$.

Dauguma jaunuju lengvaatlečiu (54\% tiriamuju) geba suderinti mokymasi ir sportinę veikla.

Raktažodžiai: socialinè aplinka, lengvoji atletika, lengvaatlečiai.

\section{IVADAS}

$O$ portinio rengimo turini, priemones ir metodus lemia sportininku amžius, lytis, sporto šakos specifika, meistriškumas, individualūs gebejjimai, socialinè aplinka ir kiti veiksniai (Пьянзин, 2004; Karoblis, 2005). Paauglysteje daugiau negu vyresniame amžiuje sportinius rezultatus lemia spartus, natūralus fizinis vystymasis, individualūs genetiniai, funkciniai, psichologiniai veiksniai, socialinė aplinka (Radžiukynas, 2005).
Sportas yra veikiamas ịvairių socialinių reiškinių, be to, pats veikia šiuos reiškinius (Стамбулова, 1999). Šiuolaikinè socialinè sporto problema yra mažejantis mokinių, norinčių kultivuoti lengvają atletiką, skaičius. Tai rodo oficiali Lietuvos lengvaatlečių varžybų statistika. Šiai situacijai įtakos gali turèti individualūs gebejjimai, saviraiškos galimybès, amžius, socialinė ugdomoji aplinka, tèvų pritarimas ir skatinimas, sporto materialinè 
bazė ir kiti veiksniai. Todèl kyla klausimas, koki poveiki socialinè aplinka turi lengvaatlečių treniruotès vyksmui.

Didelès reikšmės visapusiško sportininkų ugdymo vyksme turi trenerių, tèvų ir kitu asmenu veiksmai bei poelgiai (Goldberg, Chandler, 1995). Tèvų pritarimas, skatinimas, ivvairiapusé parama padeda vaikams atsiskleisti formalaus arba neformalaus ugdymo vyksme. Treneriai, tèvai, socialinès priežastys dažnai skatina aktyvų dalyvavimą sportinejje veikloje (Bois et al., 2005; Šarkauskienè, Adaškevičienè, 2008).

Pažymètina, kad sportuojantiems mokiniams trūksta laiko, nes reguliarios pratybos atima didžiają dalị laisvalaikio. Be to, mokymąsi ir sportavimą sunku suderinti dèl nuovargio po pratybų. Dažnai tenka praleisti pamokas dèl išvyku i varžybas. Kai sportavimo tikslai užgožia mokymosi tikslus, atsiranda nerimas. Dél pratyboms skirto laisvalaikio gali tekti atsisakyti dominančiu pomėgiu ir interesu (Стамбулова, 1999; Horton, Mack, 2000; Karanauskienè ir kt., 2004). Literatūroje aptinkame tyrimų, kurių autoriai pripažista, kad sportinè veikla teigiamai veikia mokymosi rezultatus (Spreitzer, 1994; Baxter-Jones, 1995). Kiti autoriai S. Šukys ir R. Jankauskienè (2008) teigia, kad fizinis aktyvumas nèra susijęs su geresniais mokymosi pasiekimais.

Tikètina, kad socialinè aplinka — teigiamas tẻvų požiūris ị sportinę veiklą, materialinè bazè, sportavimo ir mokymosi suderinimas skatina jaunuosius lengvaatlečius treniruotis, tobulinti sportinius gebejjimus.

Tyrimo objektas: socialinès aplinkos veiksniai, turintys įtaką 13-17 metų Lietuvos lengvaatlečių sporto pratyboms ir varžyboms.

Tyrimo tikslas - nustatyti ir palyginti jaunučių ir jaunių socialinès aplinkos veiksnius, turinčius įtakos Lietuvos lengvaatlečiu sporto pratyboms ir varžyboms.

\section{TYRIMO ORGANIZAVIMAS IR METODIKA}

Tiriamają imti sudarè 367 13-17 metų lengvaatlečiai - 179 merginos ir 188 vaikinai, parinkti serijiniu būdu. Tirti 13-17 metų lengvaatlečius pasirinkome todèl, kad šiuo amžiaus tarpsniu intensyviai formuojasi asmenybè, pervertinamos visos vertybès (Barkauskaitè, 2001). Šio amžiaus sportininkai pradeda planuoti savo sportinę ateiti, siekti geresnių sportinių rezultatų ir didesnio meistriškumo (Стамбулова, 1999).

Apklausa buvo atliekama po pratybų ir varžybų, iš anksto susitarus su treneriais, dalyvaujant tyrejjui. Tyrimo rezultatams analizuoti visi dalyviai suskirstyti $\mathfrak{i}$ tris grupes. Pirmai grupei (E 1) priskirti visi respondentai, antrai (E 2) - 13-14 m. lengvaatlečiai (jaunučių grupė), trečiai (E 3) 15-17 m. lengvaatlečiai (jaunių grupè).

Tiriamieji raštu apklausti anketų metodu. Nustatyta: 13-17 metų lengvaatlečių tèvų nuomonè apie lengvosios atletikos pratybas; sporto baziu būklè; pratybu kiekio ir sportinès patirties rodikliai; sportavimo ir mokymosi suderinamumas. Anketa parengta remiantis šiam tyrimo metodui keliamais reikalavimais (Kardelis, 2002).

Statistinė duomenų analizė atlikta kompiuterine programa STATISTICA 5.0. Tyrimo duomenims analizuoti skaičiuotas $\chi^{2}$ (chi kvadrato) kriterijus. Reikšmingumo lygmuo $\mathrm{p}<0,05-0,001$.

\section{REZULTATAI}

Net $71,1 \%$ tèvų tiki, kad jų vaikai gali pasiekti geru sportinių rezultatu (E 1 grupè) (1 pav.). Kita labai svarbi pozityvi tévų nuostata yra ta, kad jie džiaugiasi, nes jų vaikai turiningai leidžia laisvalaiki (67\% „taip“ atsakymu). 54,5\% tèvų nori, kad vaikų sportiniai rezultatai būtų geresni. İdomu ir tai: tèvai nemano, kad jų vaikams per dideli

\begin{tabular}{|c|c|c|c|c|c|c|c|c|c|c|}
\hline \multirow{3}{*}{$\begin{array}{l}1 \text { lentelè. Sporto bazių bū- } \\
\text { klès ir kokybės vertinimas } \\
(\%)\end{array}$} & Grupès & \multicolumn{3}{|c|}{ Tenkina } & \multicolumn{2}{|c|}{ Iš dalies } & \multicolumn{2}{|c|}{$\mathrm{Ne}$} & \multicolumn{2}{|c|}{ Statistiniai rodikliai } \\
\hline & Jaunučių & \multicolumn{3}{|c|}{45,5} & \multicolumn{2}{|c|}{46,2} & \multicolumn{2}{|c|}{8,3} & \multirow{2}{*}{\multicolumn{2}{|c|}{$\begin{array}{c}\chi^{2} 18,43 \\
\text { df } 2 \\
\mathbf{p}<\mathbf{0 , 0 0 1}\end{array}$}} \\
\hline & Jaunių & \multicolumn{2}{|c|}{24,7} & \multicolumn{3}{|c|}{57,8} & \multicolumn{2}{|c|}{17,5} & & \\
\hline \multirow[t]{3}{*}{$\begin{array}{l}2 \text { lentelè. Sportinis stažas } \\
\text { užsiimant lengvąja atle- } \\
\text { tika (\%) }\end{array}$} & Grupés & 1 & 2 & 3 & 4 & 5 & 6 & 7 & 8 & $\begin{array}{l}\text { Statistiniai } \\
\text { rodikliai }\end{array}$ \\
\hline & Jaunučių & 24,2 & 21,2 & 34,3 & 14,1 & 6,1 & & & & \multirow{2}{*}{$\begin{array}{c}\chi^{2} 30,27 \\
\text { df } 7 \\
\mathbf{p}<\mathbf{0 , 0 0 1}\end{array}$} \\
\hline & Jaunių & 7,6 & 23,2 & 22,7 & 29,7 & 11,9 & 1,6 & 1,1 & 2,2 & \\
\hline
\end{tabular}




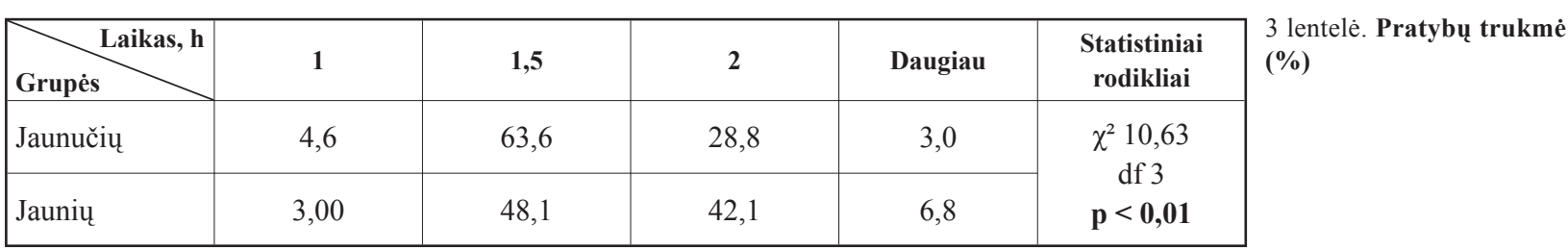
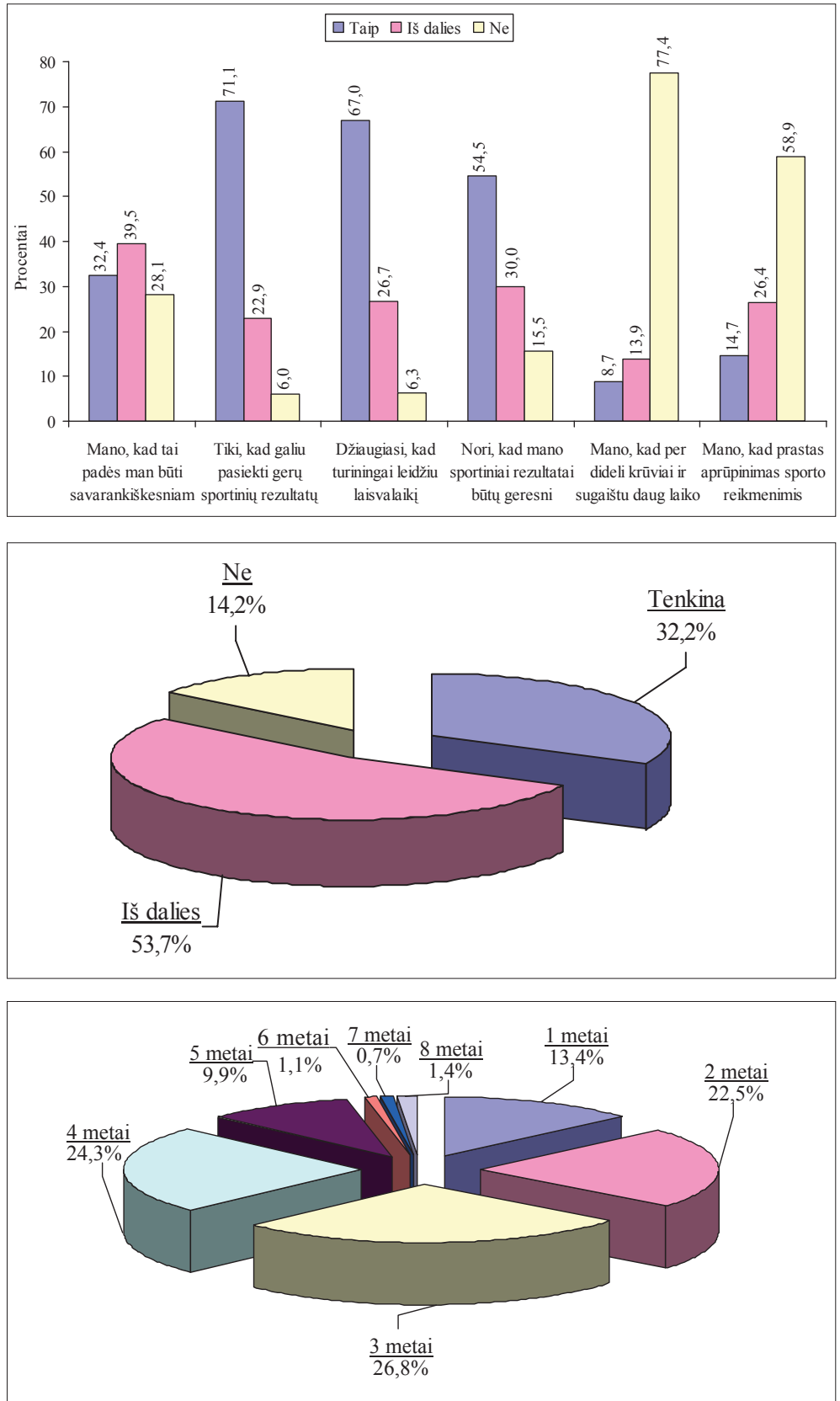

1 pav. Tiriamuju (E1 grupės) pasiskirstymas pagal tẻvų nuomonę apie lengvosios atletikos pratybas
2 pav. Tiriamųju (E 1 grupès) pasiskirstymas pagal sporto bazių būklès ir kokybès ivertinimą
3 pav. Tiriamưjų (E 1 grupès) pasiskirstymas pagal sportinę patirtị fiziniai krūviai ir sugaištama daug laiko. Galima teigti, kad vaikų užimtumo trukmè tèvams nėra svarbi, kai veikla turininga ir prasminga. 58,9\% tèvų teigia, kad jų vaikai yra pakankamai aprūpinti sporto reikmèmis.

Pažymètina, kad lengvaatlečiu jaunučių (E 2 grupès) ir jaunių (E 3 grupès) tėvų nuomonè apie lengvosios atletikos pratybas šiais klausimais statistiškai patikimai nesiskiria.

Tik 32,2\% apklaustų lengvaatlečiu (E 1 grupès) tenkina Lietuvos sporto bazių būklè ir koky- bè, 53,7\% - tenkina iš dalies (2 pav.). Jaunučius (E 2 grupès) statistiškai patikimai $(\mathrm{p}<0,001)$ daugiau tenkina sporto bazių būklè ir kokybė, lyginant su jauniais (E 3 grupè) (1 lent.). Tai galima paaiškinti šitaip: jaunučiu pratybos organizuojamos ir vykdomos remiantis visapusiško rengimo principu, todèl jas galima vykdyti gamtoje, sporto salèse ir kitose vietose, neturinčiose specialios įrangos. Jauniu pratybos sutampa su specializuotos atrankos etapu, todèl reikia geros būklès ir kokybės sporto bazių. Be to, šio amžiaus 
4 pav. Tiriamųjų (E 1 grupės) pasiskirstymas pagal pratybų skaičių per savaitę
5 pav. Tiriamųjų (E 1 grupès) pasiskirstymas pagal pratybų trukmę
6 pav. Tiriamųjų (E 1 grupès) pasiskirstymas pagal nuomonę apie neigiamą pratybų poveikị mokslui
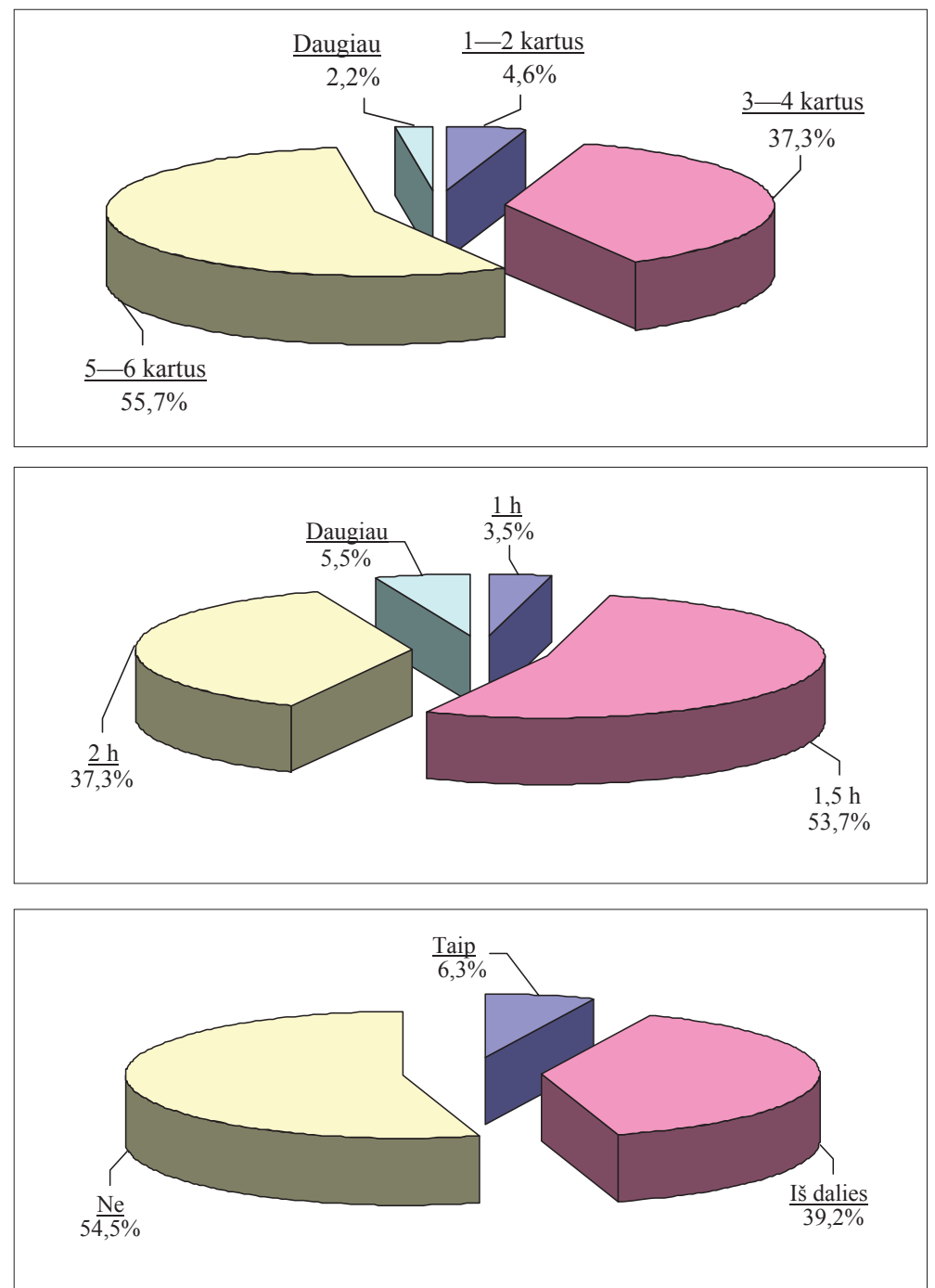

sportininkai daugiau dalyvauja varžybose ir nori pasiekti geresnių rezultatų. Didejja jų reikalavimai sporto bazès būklei ir kokybei.

Lietuvos jaunučių ir jaunių (E 1 grupès) sportinis stažas dažniausiai svyruoja nuo vienerių iki ketverių metų (3 pav.). Vadinasi, dauguma jų pradeda sportuoti būdami dešimties metų amžiaus. Tai atitinka jaunujų lengvaatlečių atrankos teoriją, kuri nusako tinkamiausią amžiaus ribą ivvairioms lengvosios atletikos rungtims (Radžiukynas, 2005).

Désninga, kad vienerių ir trejų metų sportini stažą daugiau turi jaunučiu (E 2 grupès), o ketverių ir daugiau - jaunių (E 3 grupès) tiriamieji $(\mathrm{p}<0,001)(2$ lent.).

Atliktas tyrimas parode (4 pav.), kad dauguma jaunujuc (E 1 grupès) Lietuvos lengvaatlečių treniruojasi 3-4 ir 5-6 kartus per savaitę. 13-14 metú (E 2 grupès) lengvaatlečiai daugiau treniruojasi 3-4 kartus per savaitę, 15-17 metu (E 3 grupès) - 5-6 kartus, bet statistiškai patikimo skirtumo tarp grupiu nenustatyta. Manome, kad per didelis procentas jaunučiu $(53,8 \%)$ lanko pratybas 5-6 kartus per savaitę. Tai gali daryti itaką spartesniam sportinių rezultatų augimui šiuo amžiaus tarpsniu ir jų vèlesnei stabilizacijai.

Daugumos jaunujuc lengvaatlečių (E 1 grupès) pratybos trunka 1,5 valandos ir dvi valandas (5 pav.). Jaunučiai (E 2 grupès) patikimai daugiau sportuoja 1,5 valandos, jauniai (E 3 grupès) - dvi valandas ( $p<0,01)$ (3 lent.).

Problemiškas yra formalaus mokymosi mokykloje suderinimas su lengvosios atletikos pratybomis, nes 39,2\% tiriamuju (E 1 grupès) pažymèjo, kad pratybos iš dalies trukdo mokslui (6 pav.). Esminio nuomonių skirtumo tarp jaunučių (E 2 grupès) ir jaunių (E 3 grupès) šiuo klausimu nèra.

\section{REZULTATŲ APTARIMAS}

Tyrimu siekta nustatyti, kaip tėvai vertina vaiku pasirinkimą kultivuoti lengvają atletiką, treniruotés ugdomaji, sportini poveiki. Nustatytas teigiamas tėvų požiūris ì lengvosios atletikos pratybas. Teigiamą tèvų nuomonę apie vaikų dalyvavimą fizinio ugdymo veikloje nustate ir kiti tyrèjai (Bois et al., 2005; Šarkauskienè, Adaškevičienè, 
2008). Tyrimo rezultatai rodo, kad tèvams svarbu konkretūs vaiku ugdomosios sportinès veiklos rezultatai. Tai sutampa su tyrejju D. Karanauskienès ir kt. (2004) teiginiais, kad sportuojančiu vaikų sportiniu gabumų tobulinimas tampa pačiu svarbiausiu ir jų tèvams, treneriams, mokytojams. Nemaža tėvų dalis mano, kad lengvosios atletikos pratybos padès jų vaikams būti savarankiškesniems. Taigi visiškai suprantamas tėvų noras, nes šiuolaikinèmis visuomenès raidos sąlygomis, esant dideliam ir ivvairiam informacijos srautui, tik savarankiškam darbui išugdyta asmenybė gali efektyviau ir greičiau adaptuotis ir save išreikšti informacinių sistemų valdomoje visuomeneje. Tai sutampa ne tik su visuomenès sisteminio valdymo teorija, bet ir su holistine asmenybès ugdymo samprata (Barkauskaitè, 2001).

Organizuojant treniruotès vyksmą, didelès reikšmès turi materialinè sporto bazè. Tačiau daugumos Lietuvos lengvosios atletikos sporto baziu būklè ir kokybė neatitinka tarptautinių standartų. Prasta sporto bazė gali lemti vaikų apsisprendimą renkantis sporto šaka. Tai, kad sporto materialinè bazè yra svarbus veiksnys formuojant asmenybès kūno kultūrą, pažymi ir kiti autoriai (Tamošauskas ir kt., 2004).

Pratybu kiekis (ju dažnis ir trukmè) iš dalies nusako treniruotès vyksmo intensyvumą. Priklausomai nuo amžiaus, lyties, sportinio meistriškumo, sporto šakos specifikos, treniruotès laikotarpio pratybu kiekis skiriasi (Пьянзин, 2004; Karoblis, 2005). Galima teigti, kad Lietuvos jaunujų lengvaatlečių treniruotès vyksmas pagal pratybų kiekị per savaite yra intensyvus. Tyrimo rezultatai papildo kitų autorių, tyrusių jaunujų lengvaatlečių rengimą, duomenis (Геращенко, 2000; Radžiukynas, Žilinskienè, 2008).

Jauniesiems lengvaatlečiams gali kilti sunkumų derinant mokymąsi ir sportinę veiklą. Galima teigti, kad moksleiviams, kurie lanko lengvosios atletikos pratybas, ypač 4-5 kartus, arba net 5-6 kartus per savaitę, trūksta laiko. Tai beveik sutampa su kitų tyrëjų duomenimis (Стамбулова, 1999; Karanauskienė ir kt., 2004). Mokslininkai S. Šukys ir R. Jankauskienė (2008) nustatè, kad laisvalaikiu fiziškai aktyvių mokiniu mokymosi motyvacija aukštesnė nei sportuojančių ir fiziškai pasyvių. Atsiranda spręstinų klausimų: 1) kaip patobulinti treniruotès sistema, kad per trumpesni laiką pasiektume adekvačiu arba geresnių rezultatų; 2) kaip sumažinti papildomą formalaus ugdymo krūvị, tenkanti po pamokų; 3) kokios naujos informacinès sistemos ir ugdymo technologijos gali pagreitinti žinių ir igūdžiu optimalios sąveikos efektyvumą. Tyrimo rezultatai papildo kitu tyrèju duomenis apie sportinès veiklos poveiki sportininku mokymuisi (Spreitzer, 1994; Baxter-Jones, 1995; Šukys, Jankauskienė, 2008).

Šis tyrimas papildo teiginius, kad jaunujų lengvaatlečiu treniruotès vyksmas turi atitikti mokinių, tèvų poreikius, individualius gebejjimus ir vyktų remiantis naujausiomis sporto treniruotes ir asmenybės ugdymo technologijomis (Геращенко, 2000; Пьянзин, 2004; Karoblis, 2005).

\section{IŠVADOS}

1. Socialinès aplinkos veiksniai - teigiamas tèvų požiūris î sportinę veiklą skatina treniruotis Lietuvos jaunuosius lengvaatlečius. Tèvai pritaria vaikų dalyvavimui sportinèje veikloje, nes sportuodami jie ugdo savarankiškumą, turiningai leidžia laisvalaiki, siekia konkretaus sportinio tikslo.

2. Dauguma jaunujų lengvaatlečiu geba suderinti mokymąsi ir sportinę veiklą, sportininkams tenkantis pratybų kiekis (jų dažnis ir trukmè) yra optimalus ir atitinkantis gebėjimus, tačiau pageidautina gerinti lengvosios atletikos sporto mokyklų materialinę bazę.

\section{LITERATŪRA}

Barkauskaitè, M. (2001). Paaugliai: sociopedagoginé dinamika: monografija. Vilnius: VPU.

Baxter-Jones, A. D. G. (1995). Does intensive training at young age affect educational attainment? Journal of Sports Sciences, 13 (1), 83.

Bois, J. E., Sarrazin, P. G., Brustad, R. J., Cury, F., Trouilloud, D. O. (2005). Elementary schoolchildren's perceived competence and physical activity involvement: The influence of parents' role modeling behaviors and perceptions of their child's competence. Psychology of Sport and Exercise, 6, 381-397.

Golberg, A. D., Chandler, T. (1995). Sports counseling: Enhancing the development of the high school student athlete. Journal of Counseling and Development, 74 (1), $39-45$.

Horton, R. S., Mack, D. E. (2000). Athletic identity in marathon runners: Functional focus or dysfunctional commitment? Journal of Sport Behavior, 23 (2), 101-120.

Karanauskiene, D., Kardelis, K., Šukys, S. (2004). Sportinio identiteto kaip tiriamojo konstrukto metodologiniai ypatumai. Sporto mokslas, 4 (38), 17-21.

Kardelis, K. (2002). Moksliniu tyrimu metodologija ir metodai. Kaunas: KTU.

Karoblis, P. (2005). Sporto rengimo teorija ir didaktika. Vilnius. 
Radžiukynas, D. (2005). Jaunuju lengvaatlečiu atranka ir rengimas. Vilnius: VPU.

Radžiukynas, D., Žilinskienè, N. (2008). Jaunujų šuolininkiu atranka. Sporto mokslas, 3 (53), 45-51.

Spreitzer, E. (1994). Does participation in interscholastic athletics affect adult development? Youth and Society, 25 (3), 368-388.

Šarkauskienè, A., Adaškevičienė, E. (2008). 5-6 klasių mokiniu neformaluji fizini ugdymą lemiantys veiksniai. Ugdymas. Küno kultūra. Sportas, 3 (70), 88-94.

Šukys, S., Jankauskienė, R. (2008). Mokinių sportavimo ir fizinio aktyvumo laisvalaikiu sąsajos su psichosocialiniais, elgesio ir mokyklos veiksniais. Ugdymas. Küno kultūra. Sportas, 1 (68), 92-99.
Tamošauskas, P., Poteliūnienė, S., Karoblis, P., Poviliūnas, A. (2004). Studentų fizinis ugdymas Lietuvos aukštosiose mokyklose humanistinès pedagogikos kontekste. Sporto mokslas, 2 (36), 68-74.

Геращенко, Г. А. (2000). Экспериментальные способы повышения уровня скоростно-силовых способностей у прыгунов в высоту с разбега 16-18 лет на этапе углубленной спортивной специализачии: автореферат диссертации кандидата педагогических наук. Смоленск.

Пьянзин, А. И. (2004). Спортивная подготовка легкоатлетов-прыгунов. Москва: Теория и практика физической культуры.

Стамбулова, Н. Б. (1999). Психология спортивной каpьеры. Санкт-Петербург: Центр карьеры.

\title{
SOCIAL ENVIRONMENT FACTORS INFLUENCING SPORTS TRAINING SESSIONS AND COMPETITIONS OF YOUNG ATHLETES
}

\author{
Nelè Žilinskienė \\ Vilnius Pedagogical University, Vilnius, Lithuania
}

\begin{abstract}
The social problem of the present day is that the number of schoolchildren, who would be eager to practice track-and-field events is decreasing. Such situation has been influenced by personal abilities, possibilities of self expression, age, social educational environment, approval and stimulation of parents, material facilities for sports and other factors. It is believed that the educational environment, positive approval and stimulation of parents, material facilities for sports, good harmonized arrangements for sports practice and studies can stimulate young athletes to improve theirs sports skills and abilities.

The aim of the research was to distinguish and compare the social educational environment factors, which may influence cadets and juniors to practice track-and-field events and participate in competitions.

The interview applying a questionnaire was directly held by a researcher after practice and competition events upon given prior agreements of coaches. The sample consisted of 367 13-17 year-old participants: 179 girls and 188 boys selected applying a serial principle.

According to the respondents, it has been distinguished that the parents would express their positive attitude towards practicing of track-and-field events: $71 \%$ of parents believed that their children might achieve good sports results, $67 \%$ of parents were satisfied with the fact that their children had meaningful leisure, $54 \%$ of parents expected the results of their children to be improved.

$32 \%$ of respondents were fully satisfied with the condition of material facilities for sports, $53 \%$ were satisfied partially. The response of cadets was statistically reliably $(p<0.001)$ in favor of material facilities for sports compared to the juniors.

The experience in sports practice amongst the Lithuanian cadets and juniors, who specialized in trackand-field events, accounts for the duration between one to four years (13-24\% of the respondents). This proves that majority of them start at the age of ten. It is rather consistent, that the experience of one and three years accounts for the cadets, and the experience of four years and above - for the juniors $(p<0.001)$.

The majority (54\% of the respondents) of young athletes, who practice track-and-field events, manage to coordinate their studies and sports activities well.
\end{abstract}

Keywords: social educational environment, young athletes, track-and-field events.

Gauta 2009 m. sausio 19 d.

Received on January 19, 2009

Priimta 2009 m. gegužès 6 d.

Accepted on May 6, 2009
Nelè Žilinskienè

Vilniaus pedagoginis universitetas

(Vilnius Pedagogical University)

Studentų g. 39, LT-2600 Vilnius

Lietuva (Lithuania)

Tel +37068730771

E-mail nele.zilinskiene@gmail.com arvix@taurakalnis.1t 